\title{
Health and Wellness Product from Mangosteen (Garcinia mangostana L.) Rind: Bioactive Potentials
}

\author{
Shashirekha M. Nanjarajurs ${ }^{1}$, Shylaja M. Dharmesh ${ }^{2, *}$, Shivaleela V. Bhimangouder ${ }^{1}$, \\ Mallikarjuna S. Eswaraiah ${ }^{2}$ and Rajarathnam Somasundaram ${ }^{1}$
}

\author{
${ }^{1}$ Department of Fruit and Vegetable Technology, Central Food Technological Research Institute, CSIR, \\ Mysore-570020, India \\ ${ }^{2}$ Department of Biochemistry and Nutrition, Central Food Technological Research Institute, CSIR, Mysore- \\ 570020, India
}

\begin{abstract}
Mangosteen rind (MSR) (Garcinia mangostana L.) is a predominant component of the fruit contributing to $62 \%$ of the whole fruit. However, utilization of the same for the preparation of health products was not explored due to its sensorially less acceptable parameters. Differential extraction in different polarity solvents of MSR was done and evaluated their acceptability for product preparation. Current study thus is a detailed investigation on bioactivity profiling of MSR fraction and utilization of the same for health product preparation. Among various extracts, $70 \%$ ethanol $(70 \% \mathrm{AE})$ yielded the maximum $(15 \mathrm{~g} / 100 \mathrm{~g})$. Xanthone:Phenolic ratio was $1: 2.8$, in $70 \% \mathrm{AE}$ as opposed to hot water extract - HWE and 50\% AE, which contained Xanthone:Phenolic ratio of 1:1.4/5. Higher the phenolic content obviously reduces the bitterness of Xanthones. $70 \% \mathrm{AE}$ contained phenolics $60.08 \pm 0.213 \mathrm{mg} / \mathrm{g}$ and xanthones $22.56 \pm 0.317$ $\mathrm{mg} / \mathrm{g}$. HPLC analysis revealed a spectrum of phenolic acids such as gallic, chlorogenic, caffeic, epicatechin, catechin and ferulic acids at various levels. Potent Free Radical Scavenging (FRS) activity, cytoprotectivity, DNA protectivity, $\mathrm{H}^{+} \mathrm{K}^{+}$ATPase inhibitory (PPAI) activities were observed in $70 \% \mathrm{AE}$. Gallic/tannic acid appear to contribute to antioxidant activity; while ferulic acid was responsible for PPAl activity in 70\%AE. Among xanthones, although $\alpha$ - mangostin was the dominating component, gartanin, 8 deoxygartanin and 3-isomangostin contributed to FRS activity. The products were prepared from $70 \% A E$ which are sensorially acceptable. Data thus for the first time delineate the specific health beneficial role of both phenolic and xanthone constituents in MSR particularly with higher abundance of phenolics than xanthones.
\end{abstract}

Keywords: Phenolic, Xanthone, Garcinia mangostana L., Free Radical Scavenging, Cyto/DNA.

\section{INTRODUCTION}

Garcinia mangostana L., commonly known as mangosteen, is a tropical fruit belonging to the Clusiaceae or Guttiferae family [1]. It is widely cultivated in Thailand, India, Malaysia, Srilanka, Myanmar, Phillipines, China and Indonesia. Worldwide production of $G$. mangostana is about $1,50,000$ tons per annum [2,3]. Mangosteen species are of economic and commercial interest, with tremendous demand for the fruit in domestic and export markets. Thailand is responsible for approximately $85 \%$ of the total production of $1,50,000$ tons per year. Malaysia and Indonesia are also major commercial producing countries. In the United States alone, mangosteen juice sales for 2007 were estimated at $\$ 98$ million [2].

G. mangostana is a climacteric fruit, named as "the queen of fruit" and mostly eaten fresh. Depending on the growth cycle, a single tree may produce 500 to 800 fruits in one year. The fruit is round, 2.5 to $7.5 \mathrm{~cm}$ in diameter, and weighs about 75 to $150 \mathrm{~g}$. The rind is smooth and 0.6 to $1 \mathrm{~cm}$ thick. The exterior is pale green when immature and dark purple when fully riped.

*Address correspondence to this author at the Department of Biochemistry and Nutrition, Central Food Technological Research Institute, CSIR, Mysore570020, India; Tel: (91) - 0821-2514876; Fax: (91) - 0821-2517233;

E-mail: cancerbiolab@gmail.com
The inner pulp contains 4 to 8 juicy white segments that are sweet and faintly aromatic. The fruits may or may not contain seeds $[4,5]$. The edible aril is white, soft and juicy with a sweet, slightly acid taste and pleasant aroma [6]. The pericarp / rind of the fruit is about two-thirds of the whole fruit by weight, bright purple in color, usually not eaten, and represents an agricultural waste. In fact, the non-edible pericarps have been used for treating diarrhoea, wounds and skin infection in traditional medicine [7]. The rind is rich in anthocyanins [8,9]. The anthocyanins in the rind are primarily cyanidin -3-sophoroside with smaller amounts of cyanidin [10]. The polyphenols in the pericarp of $G$. mangostana could have evolved as a defensive mechanism against herbivores and believed to contribute potentially to health beneficial effects.

Peel / rind / pericarp are often the waste part of various fruits. These wastes have not received much attention with a view to being used or recycled rather than discharged [11]. This might be due to lack of their commercial application [12]. Interestingly, the peel and seed fractions of some fruits have higher anti-oxidant activity than the pulp fractions [13]. Illustrated examples like pomegranate peel [14], apple fruit peel [15], and grape seed [16] have higher antioxidant activities than pulp.

@ 2014 Lifescience Global 
The rind of $G$. mangostana is rich in bio-active compounds with potential applications as therapeutic agents or as functional food additives [8]. In the United States, G. mangostana products are now widely available and are highly popular because of their perceived role in enhancing human health [17]. G. mangostana (MS) fruit juice has become a major dietary supplement, and was ranked as one of the top selling "botanicals" on the market in 2005 [18]. Xanthone derivatives as the major secondary metabolites of $G$. mangostana fruits [19-21], exhibit antibacterial [22,23], antifungal [24], anti-inflammatory [25], antioxidant [26,6], antiplasmodial [20] and cytotoxic activities [27, 28]. The most abundant xanthone from $G$. mangostana, $\alpha$-mangostin was found to inhibit alveolar duct formation in mouse mammary organ culture model and to suppress the carcinogen induced formation of aberrant crypt foci in a short-term colon carcinogenesis model [26,29]. As a result of these studies, the possible cancer chemo-preventive activity of $G$. mangostana has been strongly suggested.

It has to be emphasized here that $G$. mangostana rind (MSR) being the predominant component of the fruit contributing to $\sim 62 \%$ as opposed to 19,13 and $6 \%$ of pulp, seeds and stalk respectively, utilization of the same for the preparation of health products was not explored due to its sensorially less acceptable parameters. An attempt has been made from our laboratory for fractionation of MSR and evaluated their acceptability for product preparation [30]. In the current study, therefore, a detailed investigation has been undertaken to evaluate the bioactivity profiling in addition to the identification of phenolic and xanthone constituents. Outcome of the study reveals the spectrum of bioactivity in $70 \% \mathrm{AE}$ of $\mathrm{MSR}$ and utilization of the same for the product preparation.

\section{MATERIALS AND METHODS}

\section{Chemicals}

Phenolic acid standards such as gallic acid, tannic acid, caffeic acid, coumaric acid, ferulic acid, gentisic acid, protocatechuic acid, syringic acid, vanillic acid and cinnamic acid, and synthetic antioxidant namely butylated hydroxyanisole (BHA) were purchased from Sigma Chemical Co., (St. Louis, MO, USA), Other chemicals and reagents such as 1,1- diphenyl-2picrylhydrazyl (DPPH), 2-Thiobarbituric acid (TBA), Folin ciocalteau reagent, Ferrous sulphate, Ascorbic acid, Agarose and HPLC grade solvents used in the experiments were purchased from M/s Sisco Research Laboratory Pvt Ltd. (Mumbai, India), Sperm DNA from fish and Brain Heart Infusion Broth were purchased from M/s HiMedia (Mumbai, India). The HPLC column (Shimpak $\mathrm{C}_{18}$ ) was obtained from Shimadzu Corp., Tokyo, Japan.

\section{Samples}

Mature, ripe G. mangostana fruits were procured from the orchards of Ooty (Nilgiris, Tamil Nadu, India). The fruits were harvested along with peduncle. Fruits were cleaned; cut into two halves; pulp was removed and kept for further use in preparing beverages. The rind left after removal of edible pulp was sliced and dried in cabinet hot air drier (Jaydeep Engineering works, Ambalacantt, Harayana, India) $\left(\sim 55^{\circ} \mathrm{C}\right)$. The dried rind slices were subjected to Apex mill (M/s Cadmach Machinery Co., Ltd. Germany) to obtain a powder ( 1mm particle size). The dried powder (with residual moisture of $\sim 5 \%$ ) was stored in polypropylene bottles in the refrigerator $\left(5^{\circ} \mathrm{C}\right)$ till use.

\section{Extraction}

The dried powder $(100 \mathrm{~g})$ was soaked and extracted in $1000 \mathrm{~mL}$ of hot water $\left(\sim 60^{\circ} \mathrm{C}\right), 50 \%(\mathrm{v} / \mathrm{v})$ and $70 \%$ ethanol $(\mathrm{v} / \mathrm{v})$ separately. Extracts were flash evaporated at $40^{\circ} \mathrm{C}$ and a reduced volume was dried in hot air oven $\left(\sim 50^{\circ} \mathrm{C}\right)$, weighed and stored in a refrigerator $\left(5^{\circ} \mathrm{C}\right)$ until use. They were designated as Hot Water (HWE), 50\% Alcohol (50\%AE) and 70\% Alcohol Extracts $(70 \% \mathrm{AE})$ respectively. The yield of extraction was expressed as \% on dry weight basis. 50 $\mathrm{mg}$ of $G$. mangostana rind powders (MSR - HW, $50 \% \mathrm{AE}, 70 \% \mathrm{AE}$ ) were resuspended in $1 \mathrm{~mL}$ of respective solvents. All the extracts were stored at $4^{0} \mathrm{C}$ till the completion of the experiment.

\section{Estimation of Total Phenolics}

The total phenolic content of HWE, $50 \% \mathrm{AE}$ and $70 \% \mathrm{AE}$ was determined spectrophotometrically using the Folin-phenol reagent [31]. Sample aliquot of $100 \mu \mathrm{L}$ was added to $900 \mu \mathrm{L}$ of water, $1 \mathrm{~mL}$ of Folin-Ciocalteu reagent, and $2 \mathrm{~mL}$ of $10 \%$ sodium carbonate solution, mixed in a cyclomixer, and incubated for $1 \mathrm{~h}$ at room temperature. The absorbance was measured at 765 $\mathrm{nm}$ with a Shimadzu UV-visible spectrophotometer. The standard curve was drawn using $10-100 \mu \mathrm{g}$ of gallic acid. The total phenolic content was expressed as gallic acid equivalent (GAE) in milligrams per gram of sample [32]. 


\section{Determination $\mathrm{H}^{+}, \mathrm{K}^{+}$-ATPase Inhibition (PPAI)}

Parietal cells were collected from Fresh sheep stomach, homogenized in $0.2 \mathrm{M}$ Tris buffer $(\mathrm{pH} 7.4)$ containing $10 \%$ Triton $\mathrm{X}-100$ and centrifuged at $6000 \mathrm{~g}$ for $10 \mathrm{~min}$. The supernatant (enzyme extract) was used for the assay [33]. The enzyme extract $(5900 \mu \mathrm{g} / \mathrm{mL})$ was incubated with different fractions of $G$. mangostana rind extracts, in a reaction mixture containing $0.2 \mathrm{M}$ Tris buffer ( $\mathrm{pH} 6.5)$, and the reaction was initiated by adding substrate $2 \mathrm{mM}$ ATP, in addition to $2 \mathrm{mM} \mathrm{MgCl} 2$ and $2 \mathrm{mM} \mathrm{KCl}$. After $30 \mathrm{~min}$ of incubation at $37{ }^{\circ} \mathrm{C}$, the reaction was stopped by the addition of the assay mixture containing $3.6 \%$ ammonium molybdate and $20 \%$ perchloric acid. Inorganic phosphate formed was measured spectrophotometrically at $400 \mathrm{~nm}$. Enzyme activity was calculated as micromoles of $\mathrm{Pi}$ released per hour at various doses $(10-30 \mu \mathrm{L})$ of MSRE water and methanol extracts. Results were compared with the known antiulcer proton potassium ATPase inhibitor drug Lansoprazole.

\section{Measurement of Antioxidant Activity}

Antioxidant activity of $G$. mangostana rind extracts was determined as free radical scavenging activity of the stable 1, 1-diphenyl-2-picrylhydrazyl (DPPH) free radical [32].

G. mangostana rind extracts both water and methanol extracts at various concentrations $(5-30 \mu \mathrm{g}$ $\mathrm{GAE} / \mathrm{mL}$ ) were added to $1 \mathrm{~mL}$ of $0.004 \%$ methanol solution of DPPH. The mixture was shaken vigorously and left to stand for $20 \mathrm{~min}$ at room temperature in the dark. The absorbance of the resulting solution was measured spectrophotometrically at $517 \mathrm{~nm}$. The capability to scavenge the DPPH radical was calculated using the following equation.

Free Radical Scavenging effect $(\%)=\left\{\begin{array}{l}\text { Absorbance of control at } 517 \mathrm{~nm}- \\ \text { Absorbance of sample at } 517 \mathrm{~nm} \\ \frac{\text { Absorbance of control at } 517 \mathrm{~nm}}{}\end{array}\right\} \times 100$

\section{Measurement of Cytoprotective Ability}

\section{Effect on Red Blood Cells (RBC)}

To $1 \mathrm{~mL}$ of $10 \%$ suspension of erythrocytes in phosphate buffer saline (20 mM PBS, pH 7.4) was added, $150 \mu \mathrm{L}$ of $50 \mathrm{mM}$ ascorbic acid and $15 \mu \mathrm{L}$ of 80 $\mathrm{mM} \mathrm{FeSO}_{4}$ in presence and absence of $10-30 \mu \mathrm{g}$ GAE of MSRHWE. After incubating the sample at 37 ${ }^{0} \mathrm{C}$ for $30 \mathrm{~min}$, the tubes were centrifuged at $3000 \mathrm{~g}$ for
$10 \mathrm{~min}$ and to $800 \mu \mathrm{L}$ of the supernatant, PBS was added to the final volume of $2 \mathrm{~mL}$ and absorbance was read at $A_{410} \mathrm{~nm}$. Oxidative damage resulted in oxidation of Red Blood Cells (RBC) leading to RBC lysis and release of Haemoglobin content from them. Taking water as a lysing agent, ensured $>90-100 \%$ lysis of RBC in the oxidized controls. Percent inhibition of RBC lysis was considered as protective effect. Concentration required to inhibit $50 \%$ of RBC lysis is considered in the experiment and expressed as $\mathrm{IC}_{50}$ at $\mu \mathrm{g}$ GAE/mL [34].

\section{Effect on Buccal Cells (BC)}

Buccal cells $\left(1 \times 10^{4}\right.$ cells/well $)$ were exposed to UV radiation and a carcinogen- $\mathrm{N}$-nitroso- $\mathrm{N}$-methyl urea $\left(10 \mu \mathrm{g} / \mathrm{mL}\right.$ for $1 \times 10^{4}$ cells $/$ well), in presence and absence of $10 \mu \mathrm{g} \mathrm{GAE}$ of samples for $1 \mathrm{~h}$ at $37^{\circ} \mathrm{C}$. Twenty five microliters of cell suspension of both treated and untreated cells were mixed with $1 \mu \mathrm{L}$ of dye mix containing $100 \mu \mathrm{g} / \mathrm{mL}$ each acridine orange and ethidium bromide and observed under the microscope at $40 \mathrm{X}$. Viable cells stained green with acridine orange whereas damaged cells stained more orange due to ethidium bromide staining of nuclear components. Staining pattern between untreated and UV treated cells were compared and cytoprotective ability of MSREs was determined.

\section{Measurement of DNA Protective Ability}

The DNA protective effect of extracts was determined electrophoretically (Submarine Electrophoresis System, Bangalore Genei, Bangalore, India) using calf thymus DNA ( $1 \mathrm{mg} / \mathrm{mL})$ [35]. The DNA was subjected to oxidation by Fenton's reagent (100 $\mu \mathrm{M}$ ascorbic acid and $10 \mu \mathrm{M} \mathrm{FeSO}_{4}$ ) followed by gel electrophoresis. Relative difference in the migration between the native and the oxidized DNA was ensured on $1 \%$ agarose gel electrophoresis after staining with ethidium bromide. Gels were documented and the intensity of the bands was determined. Protection to DNA was calculated based on the DNA band intensity comparing with that of the native in the presence and absence of extracts.

\section{HPLC of Phenolics}

Phenolic acids in the three extracts were analyzed according to the method of Wulf \& Nagel [36], on a reversed phase Shimpak $C_{18}$ column $(4.6 \times 150 \mathrm{~mm})$, using a diode array detector (operating at $280 \mathrm{~nm}$ ). The Shimpak $\mathrm{C}_{18}$ HPLC column was obtained from Shimadzu Corp. A solvent system consisting of water / acetic acid / methanol (80:5:15) ( $/ / \mathrm{v} / \mathrm{v})$ was used as 
mobile phase at a flow rate of $1 \mathrm{~mL} / \mathrm{min}$. Phenolic acids such as gallic acid, tannic acid, caffeic acid, coumaric acid, ferulic acid, gentisic acid, protocatechuic acid, syringic acid, vanillic acid and cinnamic acid were used for the identification of phenolic acids present in the three extracts. Quantitation of phenolic acids was achieved by the absorbance recorded in the chromatograms related to external standards at 280 $\mathrm{nm}$.

\section{HPLC Analysis of Xanthones}

Dried, ground G. mangostana rind was extracted in acetone-water mixture $(80: 20 \mathrm{v} / \mathrm{v})$ for $30 \mathrm{~min}$ at room temperature .The sample was filtered through a 0.45 $\mu \mathrm{m}$ filter and $10 \mu \mathrm{L}$ of the sample was injected to HPLC (Shimadzu LC10 AVP chromatography system, Tokyo, Japan) that was conducted using $\mathrm{C}_{-18}$ column. The mobile phase consisted of A: $0.1 \%$ formic acid in water and $\mathrm{B}$ : methanol; optimal separations were achieved using a gradient of 65 to $90 \%$ B over $0-30 \mathrm{~min}$ at the flow rate of $1 \mathrm{~mL} / \mathrm{min}$. UV spectra were collected across the range of $200-400 \mathrm{~nm}$, extracting $254 \mathrm{~nm}$ for chromatograms [37].

\section{Preparation of the Health Products from the G. mangostana Rind Extract}

Health products like beverage and jelly were prepared using $70 \%$ Alcohol Extract $(70 \% \mathrm{AE})$ fraction of G. mangostana rind. $250 \mathrm{mg}$ of $70 \%$ AE in $100 \mathrm{~mL}$ water, yielded pleasant colored beverage after adjusting the acidity with citric acid to $0.3 \%$ and addition of sucrose to reach $15^{\circ} \mathrm{B}$. After filling the glass bottles $180-200 \mathrm{~mL}$, followed by crown corking, they were pasteurized at $85^{\circ} \mathrm{C}$ for $20 \mathrm{~min}$, cooled, wiped and stored at room temperature. Jelly was prepared by heating the juice obtained by dissolving the $70 \% \mathrm{AE}$ of G. mangostana rind at $250 \mathrm{mg} / 100 \mathrm{~mL}$, after adjusting the acidity to obtain $\mathrm{pH}$ of $\sim 3.3$, along with 55 parts of sugar to every 45 parts of juice followed by addition of $1.4 \%$ pectin and boiling to reach $65^{\circ} \mathrm{B}$. The mass is allowed to set after pouring hot, into glass bottles $(500 \mathrm{~mL})$. Sodium benzoate $(236 \mathrm{ppm})$ was used as preservative. Sensory and microbial analyses were performed to understand the acceptability and microbial load respectively $[38,39]$

\section{Statistical Analysis}

All the experiments were carried out in triplicates and the results are expressed as mean \pm standard deviation (SD). Correlation between the activity and phenolic and xanthone composition was calculated as coefficient of determination -R2 using linear regression model to understand the strong, moderate or weak linear trend employing the statistical programme SPSS for Windows; Version 10.0. P value was calculated by the Mann-whitney test. $P$ value $<0.05$ is considered as significant.

\section{RESULTS AND DISCUSSION}

G. mangostana fruits processed with $100 \mathrm{Kg}$ yielded a rind of about $62 \%$ in addition to pulp (19\%), seeds $(13 \%)$ and the stalk $(6 \%)$. Dried rind powder $(100 \mathrm{~g})$ after extraction yielded $4.5 \mathrm{~g}, 6.0 \mathrm{~g}$ and $15.0 \mathrm{~g}$ of residues. Different levels of phenolics and xanthones were present in these fractions. The total phenolic content in three extracts is depicted in Table 1. The phenolic content was almost 2 folds higher in $50 \%$ $(72.76 \pm 0.345 \mathrm{mg} \mathrm{GAE} / \mathrm{g})$ and $70 \%(65.08 \pm 0.213 \mathrm{mg}$ $\mathrm{GAE} / \mathrm{g}$ ) alcoholic extracts (AE) compared to that of HWE (32 $\pm 0.261 \mathrm{mg} \mathrm{GAE} / \mathrm{g})$. Xanthone was also in significant quantities in all the three extracts. Due to high abundance of total yield $70 \% \mathrm{AE}$ predominated with xanthones similar to that of phenolics (Table 1). The ratio between Xanthones: Phenolics were found to 1:1.5, 1:1.4 and 1:2.8 in HWE, 50\%AE and $70 \% \mathrm{AE}$ respectively (Table 1 ).

\section{Bioactivity in MSRE}

\section{$\mathrm{H}^{+} K^{+}$-ATPase Inhibition and Free Radical Scavenging Activity}

$\mathrm{H}^{+}, \mathrm{K}^{+}$-ATPase is an enzyme responsible for the release of $\mathrm{H}^{+}$into the lumen of the stomach leading to

Table 1: Yield, Total Phenolic/Xanthone Content and their Ratio in G. mangostana Rind Extract

\begin{tabular}{|c|c|c|c|c|}
\hline Sample & Yield of extract (\%) & $\begin{array}{c}\text { Total phenolic Content } \\
\text { (mgGAE/g) }\end{array}$ & $\begin{array}{c}\text { Total xanthones content } \\
\text { ( mg/g) }\end{array}$ & $\begin{array}{c}\text { Xanthone: } \\
\text { Phenolic }\end{array}$ \\
\hline \hline HWE & $4.5 \pm 0.43$ & $32.00 \pm 0.261$ & $20.8 \pm 0.86$ & $1: 1.5$ \\
\hline $50 \%$ AE & $6.0 \pm 0.55$ & $72.76 \pm 0.345$ & $52.23 \pm 0.301$ & $1: 1.4$ \\
\hline $70 \%$ AE & $15.0 \pm 1.15$ & $65.08 \pm 0.213$ & $22.56 \pm 0.370$ & $1: 2.8$ \\
\hline
\end{tabular}

Total weight was determined after extracting with Hot water $(\mathrm{HW}), 50 \%$ alcohol $(50 \% \mathrm{~A})$ and $70 \%$ alcohol $(70 \% \mathrm{~A})$, followed by powdering. Total phenolic and xanthone contents were determined as described under materials and methods. Values are expressed as mean of three replicates \pm standard deviation. 
Table 2: $\quad \mathrm{IC}_{50}$ of Various Bioactivities of G. mangostana Rind Extract

\begin{tabular}{|c|c|c|c|c|c|}
\hline \multirow[b]{2}{*}{ Samples * } & \multicolumn{5}{|c|}{$\mathrm{IC}_{50}$ of different activities in $\mu \mathrm{g} / \mathrm{mL}$} \\
\hline & $\begin{array}{c}\text { Total phenolic } \\
\text { content (mg } \\
\text { GAE/g) }\end{array}$ & FRS activity & RBC protection & DNA protection & PPAI \\
\hline HWE & $32.00 \pm 0.26$ & $82.48 \pm 0.28(1)$ & $84.6 \pm 0.32(1.1)$ & $8.36 \pm 0.16(1.4)$ & $7.6 \pm 0.15(16)$ \\
\hline $50 \% \mathrm{AE}$ & $72.76 \pm 0.34$ & $88.35 \pm 0.15(1.2)$ & $101.5 \pm 0.26(1.2)$ & $15.87 \pm 0.54(1)$ & $164.58 \pm 0.32(1)$ \\
\hline $70 \% \mathrm{AE}$ & $65.08 \pm 0.21$ & $122.02 \pm 0.35(2.25)$ & $316 \pm 0.18(1)$ & $11 \pm 0.32(3.6)$ & $19.96 \pm 0.36(20)$ \\
\hline $\begin{array}{c}{ }^{*} \text { Gallic acid } \\
{ }^{*} \text { Ascorbic acid } \\
{ }^{*} \mathrm{BHA}^{*} \\
\text { Lansoprazole }\end{array}$ & & $1.2 \pm 0.27$ & $13.9 \pm 0.67$ & $0.625 \pm 0.25$ & $19.31 \pm 2.3$ \\
\hline
\end{tabular}

*indicates standards.

Results in the parenthesis indicates relative fold difference in the activity.

Hot water (HWE), 50\% alcohol (50\%AE) and $70 \%$ alcohol $(70 \% \mathrm{AE})$ extracts were examined for free radical scavenging (FRS), Red blood cell protectivity, DNA protectivity and Inhibition of $\mathrm{H}^{+} \mathrm{K}^{+}$-ATPase activity (PPAI). Results are expressed as concentration required in $\mu \mathrm{g} / \mathrm{mL}$ to inhibit $50 \%$ of activity (IC $\mathrm{F}_{50}$ ). Respective standards were also included in the experiment. Values provided are mean of three replicates \pm standard deviation. Considering the $\mathrm{IC}_{50} \mathrm{Values}$ provided in Table 2 for various bioactivity and the total abundance of phenolics in Table 1, total activity was calculated. Minimum activity is taken as 1 fold and relative fold differences were expressed for each activity in different fraction.

hyperacidity and gastric ulcerations. Inhibitors of $\mathrm{H}^{+}, \mathrm{K}^{+}$ATPase enzyme therefore are gastroprotective [33]. Significant inhibition of $\mathrm{H}^{+}, \mathrm{K}^{+}$-ATPase was observed with $\mathrm{IC}_{50}$ of $7.60 \pm 0.15,164.58 \pm 0.32,19.96 \pm 0.36 \mu \mathrm{g} / \mathrm{mL}$ in $\mathrm{HWE}, 50 \% \mathrm{AE}$ and $70 \% \mathrm{AE}$ fractions respectively, when compared to $I_{50}$ of $19.31 \pm 2.3 \mu \mathrm{g} / \mathrm{mL}$ of lansoprazole (Table 2), a known proton pump inhibitor. The extracts showed free radical scavenging activity with $\mathrm{IC}_{50}$ of $82.48 \pm 0.28,88.35 \pm 0.15$ and $122.02 \pm 0.35$ in HWE, 50\%AE and 70\% AE respectively (Table 2 ).

\section{Cyto/DNA Protectivity}

Red Blood Cells (RBC's) were used as a model to study the cytoprotective ability of MSRE. Free radicals generated by Fenton's reagent by its thermal decomposition attacked the erythrocytes to induce a chain oxidation of lipid and protein, disturbing the membrane organization and eventually leading to hemolysis [34]. $50 \mathrm{mM}$ and $80 \mathrm{mM}$ concentration of ascorbic acid and ferrous sulphate could induce $100 \%$ hemolysis in human erythrocytes. A protective effect was evident as we could see the inhibition of hemolysis as measured at $535 \mathrm{~nm}$. Results indicated that HWE had more potent cytoprotective ability than other samples with $\mathrm{IC}_{50}$ of $84.6 \pm 0.32 \mu \mathrm{g} / \mathrm{mL}$. $50 \% \mathrm{AE}$ and $70 \% A E$ showed an $\mathrm{IC}_{50}$ of $101.5 \pm 0.26$ and $316 \pm 0.18$ $\mu \mathrm{g} / \mathrm{mL}$ respectively against $\mathrm{IC}_{50}$ of the standard $\mathrm{RBC}$ protectant - Ascorbic acid which showed effective inhibition at $13.9 \pm 0.67 \mu \mathrm{g} / \mathrm{mL}$ (Table 2).

The efficiency of phenolic acid extracts of mangosteen rind extracts in preventing oxidative damage of DNA was also evaluated. The hydroxyl radical generated by Fenton's reagent caused DNA fragmentation. This fragmentation was recovered by the treatment of different phenolic acid extracts in addition to BHA. The intensity of bands (Figure 1A) was measured by densitometry and percentage of protection of DNA was calculated. $I C_{50}$ of the extracts is as follows - $8.36 \pm 0.16,15.87 \pm 0.54$ and $11 \pm 0.32 \mu \mathrm{g} / \mathrm{mL}$ was observed in $\mathrm{HWE}, 50 \% \mathrm{AE}$ and $70 \% \mathrm{AE}$ fractions respectively (Table 2 ).

Due to limitations in the sample, only $70 \%$ AE was examined for its ability to protect mammalian buccal cells against UV and MNU induced cellular damage. Control cells were symmetrical, flattened with cytoplasm and the nucleus. UV and MNU treatment damaged the cell as evidenced by the alterations in their structural integrity. However, cells treated prior with $70 \% \mathrm{AE}$ showed complete protection, even better than those that were pretreated with a potent antioxidant - gallic acid (Figure 1B).

\section{Determination of Constituents in MSRE}

\section{Phenolic Composition by HPLC}

Phenolic acids present in these three extracts have been analyzed by HPLC to quantitatively determine their composition and the abundance based on the respective standard. Figure $\mathbf{2 a}$ provides the HPLC profile of standard phenolic acids and phenolic acids present in MSRE fractions. Data compiled in Table 3, expresses the phenolic acid content in $\mathrm{mg} / \mathrm{g}$ on dry weight basis of these fractions. HWE contained gallic, chlorogenic and caffeic acid; while, increased levels of gallic and chlorogenic acids were observed in $50 \%$ and $70 \%$ alcohol fractions. In $70 \%$ alcohol fraction, 

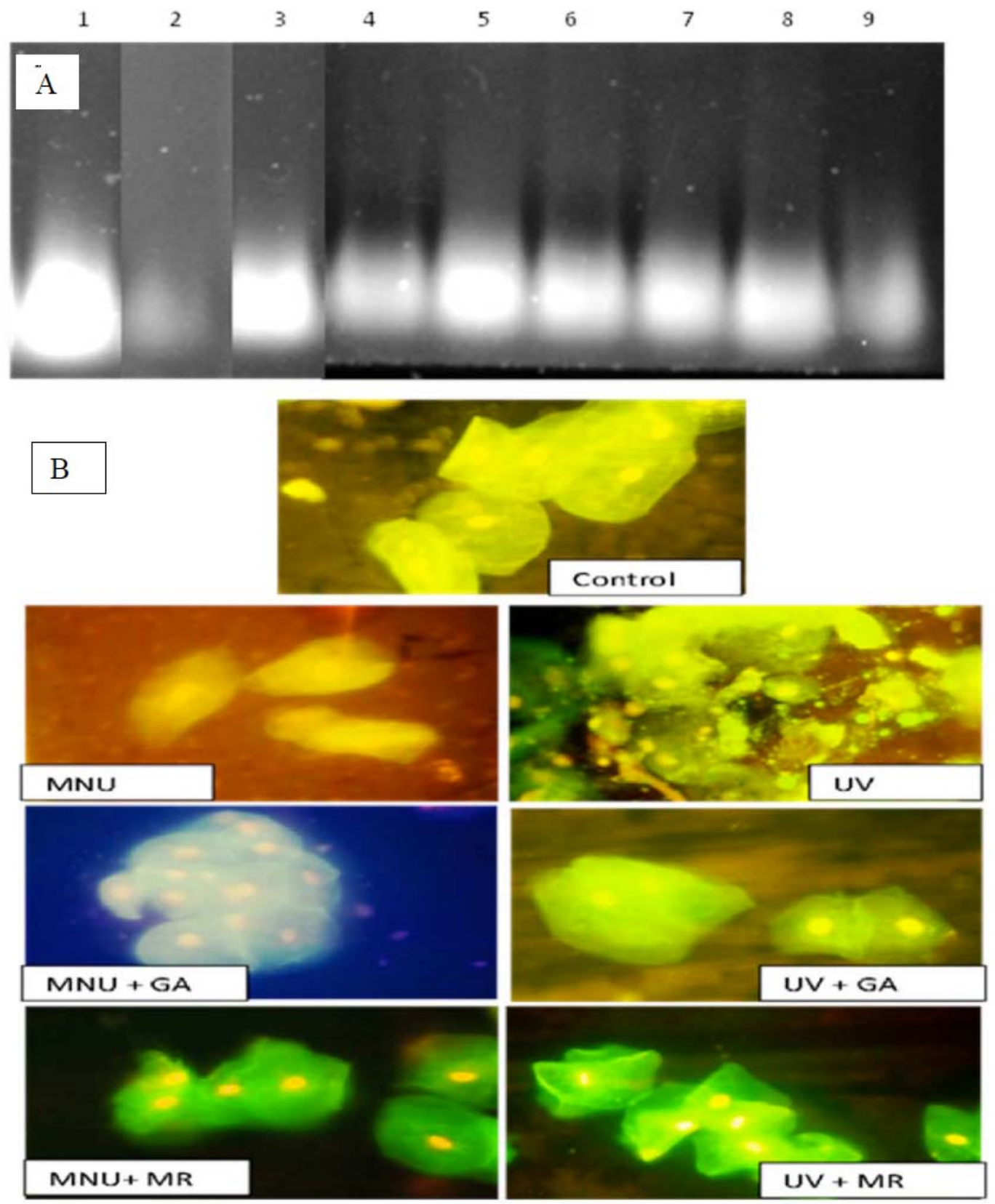

Figure 1: A. Electrophoresis analysis of DNA protection by G. mangostana extracts. Lanes 1: Native DNA; 2: Oxidized DNA; 3 :

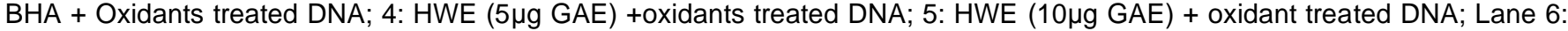

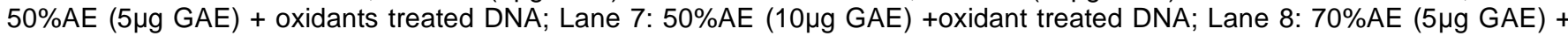

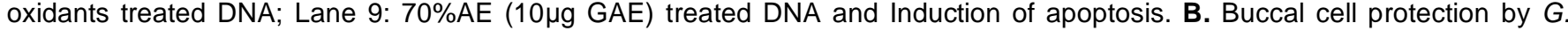
mangostana extracts. MNU- N-nitroso -N-methyl urea, UV-Ultra Violet radiation, GA-Gallic acid, MR- Mangosteen Rind extract.

significant levels of gallic/tannic acid ( 7 folds higher than HWE and 50\% AE), chlorogenic acid (about 10 folds higher), epicatechin (about 10 folds higher) and ferulic acid (about 4 folds higher) and catechin similar to that found in HWE and $50 \%$ AE were observed. Based on the $\mathrm{IC}_{50}$ value, we calculated the total activity expressed in each fraction in terms of total phenolic content. Relative fold activity was also calculated taking the least activity expressed as 1 fold in each of the activity. As indicated in Table 2, about 2-20 folds higher activity was observed in $70 \%$ AE. Further, since we had established previously the precise contribution of each of these phenolic acids in antioxidant and PPAI activity [33], we determined the effective phenolic acids contributing to free radical scavenging and PPAI activity; gallic/tannic and ferulic acids found to contribute to the activity.

Similarly we attempted to determine the contribution of various xanthones present in the fraction to 


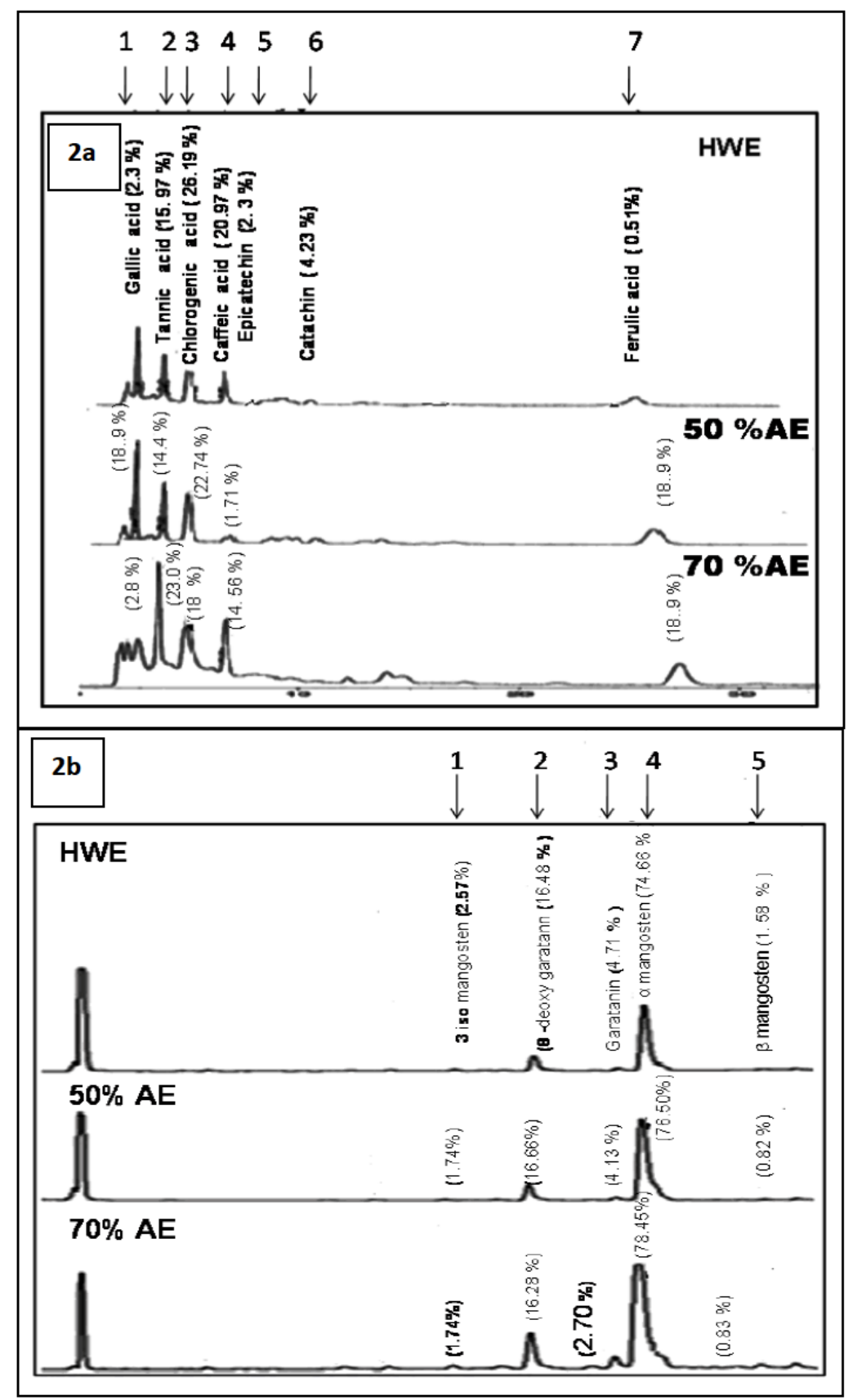

Figure 2: HPLC analysis of phenolic acid constituents and xanthones in G. mangostana rind extract.

Phenolic acids in each fraction were identified by comparison of their retention time with known standards. Retention of standards are indicated by arrows. (2a) 1-gallic acid, 2-tannic acid, 3-chlorogenic acid, 4-caffeic acid, 5-epicatechin, 6-syringic acid, 7-catechin, 8-ferulic acid. (2b) 1. $\alpha$-Mangostin, 2. Gartanin, 3. 8-Desoxygartanin, 4. $\beta$-Mangostin, 5.3-Isomangostin.

bioactivities examined (Table 3). Xanthones were resolved as a-mangostin, gartanin, 8-desoxygartanin, $\beta$-mangostin and 3-isomangostin (Figure 2b). $\alpha$ mangostin and 8-desoxygartanin were found as major components in all the extracts. However, differences in the ratios of $\alpha$-mangostin, gartanin, $\beta$-mangostin and 3isomangostin were observed. Since this being the first paper to report the comparative efficacy of different xanthones on various bioactivity, correlation coefficient
- R2 between the levels of xanthones and bioactivity was determined with level of significance of $P$ value < 0.05 , using the statistical program SPSS for windows, version 10.0. Free radical scavenging (FRS) and RBC protection (RP) activity correlated with the levels of gartanin with R2 value of 0.995 and 0.949 for FRS and $R P$ activity with $P$ value $<0.05$. However, DNA protection, and $\mathrm{H}^{+} \mathrm{K}^{+}$-ATPase inhibition correlated with $\beta$-mangostin with $R 2$ value of $>0.9$ with $P$ value $<0.05$. 
Table 3: Phenolics and Xanthones Profile in the Extracts of G. mangostana Rind

\begin{tabular}{|c|c|c|c|}
\hline Constituents & HWE & 50\% AE & 70\% AE \\
\hline \hline Phenolics & \multicolumn{3}{|c|}{} \\
\hline Gallic/Tannic & $1.52 \pm 0.038$ & $2.93 \pm 0.058$ & $15.05 \pm 0.57$ \\
\hline Chlorogenic & $0.74 \pm 0.011$ & $0.9 \pm 0.009$ & $9.0 \pm 0.085$ \\
\hline Caffeic & $0.54 \pm 0.011$ & - & $0.31 \pm 0.004$ \\
\hline Epicatechin & -- & $0.71 \pm 0.009$ & $7.27 \pm 0.174$ \\
\hline Catechin & $0.8 \pm 0.012$ & $0.95 \pm 0.015$ & $0.91 \pm 0.010$ \\
\hline Ferulic & $5.8 \pm 0.10$ & $2.06 \pm 0.04$ & $8.50 \pm 0.153$ \\
\hline Xanthones & & $39.9 \pm 0.650$ & $17.6 \pm 0.152$ \\
\hline -Mangostin & $15.5 \pm 0.307$ & $2.16 \pm 0.080$ & $0.607 \pm 0.007$ \\
\hline G-Desoxygartanin & $0.98 \pm 0.045$ & $8.6 \pm 0.102$ & $3.66 \pm 0.132$ \\
\hline 3-Mangostin & $3.42 \pm 0.243$ & $0.42 \pm 0.020$ & $0.186 \pm 0.003$ \\
\hline
\end{tabular}

Various extracts of G. mangostana rind were subjected to HPLC analysis along with phenolic acid and xanthone standards. Based on the concentration of the standard and the peak area, concentration of phenolic acidsand xanthones were calculated and expressed as $\mathrm{mg} / \mathrm{g}$. Values provided are mean of three replicates \pm standard deviation.

3-Isomangostin may also contribute to the DNA protectivity, since it also showed an $\mathrm{R} 2$ of $>.9(\mathrm{P}<0.05)$. A derivative of gartanin, 8- deoxy gartanin although showed good Correlation with R2 of $.95(P<0.05)$, did not show good correlation with other assays (Table 4). Data thus suggest that the observed activity in MSRE is mainly from a minor components such as Gartanin, $\beta$-mangostin and 8-desoxy gartanin indicating that differential interaction of different components of MSRE with specified chemical structural components may be responsible for exhibiting bioactivity. Data is supported by another study where they also indicated that gartanin than $\alpha$-mangostin may execute the activity [40]. In vivo efficacy of these components needs to be analyzed in order to understand the biotransformation of the compounds and attributing of bioactivity to the human system. Such studies are underway in the laboratory in order to find the potential bioutilization of the major ingredients of MSRE. The products prepared from the 70\%AE (both beverage and jelly) tasted sweet with pleasant aroma, and color. Microbiological and sensory examination shows the suitability of the product for human consumption. The G. mangostana jelly product has been patented (2934/DEL /2011 Dated 22-9-2011). Detailed invention on the product was covered in the above mentioned patent.

The current study is important in that it delineates the bioactive potentials and bioactive components in G.mangostana, which can throw light on the precise molecule(s) involved in varieties of health beneficial properties. Over past decades the "Queen of tropical fruits"- G. mangostana has been the subject for utilization of naturals for human health and wellness. Different parts of $G$. mangostana, mostly fruit hull, bark and roots have been used for hundreds of years in Southeast Asia as a medicine for a great variety of medical conditions. In India, Thailand, China and other parts of Asia dried and powdered fruit hull is used as antimicrobial agents and for the antiparasitic treatments in dysentery $[21,41,42]$. Mangosteen leaves and barks have shown anti-inflammatory properties [6]. G

Table 4: Correlation Co-Efficient between Different Bioactivity and Various Xanthone Components of G. mangostana Rind Extracts

\begin{tabular}{|c|c|c|c|c|c|}
\hline & a-Mangostin & Gartanin & 8-Deoxygartanin & $\beta$ - Mangostin & 3-Isomangostin \\
\hline \hline FRS & $0.6822(p<0.31)$ & $0.995(p<0.0049)$ & $0.95(p<0.04)$ & $0.89(p<0.104)$ & $0.97(p<0.02)$ \\
\hline RBC & $0.369(p<0.60)$ & $0.95(p<0.048)$ & $0.755(p<0.24)$ & $0.858(p<0.14)$ & $0.878(p<0.121)$ \\
\hline DNA & $0.574(p<0.475)$ & $0.871(p<0.128)$ & $0.889(p<0.11)$ & $0.963(p<0.036)$ & $0.957(p<0.04)$ \\
\hline PPAI & $0.04(p<0.95)$ & $0.625(p<0.374)$ & $0.515(p<0.48)$ & $0.889(p<0.116)$ & $0.732(p<0.207)$ \\
\hline
\end{tabular}

Correlation coefficient - R2 between the levels of xanthones and various bioactivities such as free radical scavenging, Red Blood Cell protection, DNA protection and PPAI was determined using the statistical programme SPSS for windows, version 10.0, with level of significance of P value $<0.05$. 
mangostana extracts were also used as tonic for various ailments [26,43] particularly as antimicrobial agent [22,23], antidiabetic, gastrointestinal health [4] etc. Based on these reports some products were also developed and sold in the market with a claim of health beneficial properties [1]. However as reviewed by Obolskiy [1], despite the generation of product of $G$. mangostana as juice, dried powder, decoction in the market, their claims were purely on the traditional knowledge only. As a result of this some of the global market issues concerning the $G$.mangostana food products existed. It is therefore pointed out by the reviewer of Obolskiy and his group [1] that it is unfortunate to witness the marketing strategies of mangosteen that reached levels of dishonest advertisement and misleading claims about the products. In this context it is imperative for food scientists to study and evaluate the bioactive potentials of $G$. mangostana. Current paper adds scientific values to G.mangostana product (s) that has potentials in the global market. Study highlights the precise of role of phenolics and xanthones in health and wellness properties.

\section{CONCLUSION}

G. mangostana rind being the major fruit portion constituting $62 \%$ of the whole fruit has been underutilized. The results of the study proved that the rind extracts which are rich in phenolics, flavonoids and xanthones possessed varied degree of bioactive potentials. The extracts can be incorporated into products preparation which is of health importance.

\section{ACKNOWLEDGEMENT}

The authors thank the Director, CSIR-Central Food Technological Research Institute, Mysore, India, for his constant encouragement throughout the course of the study.

\section{ABBREVATIONS}

$\begin{array}{ll}\mathrm{DPPH} & =1,1-\text { diphenyl-2-picrylhydrazyl } \\ \mathrm{BHA} & =\text { Butylated hydroxyanisole } \\ \mathrm{HWE} & =\text { Hot water extract } \\ 50 \% \mathrm{AE} & =50 \% \text { Alcoholic extract } \\ 70 \% \mathrm{AE} & =70 \% \text { Alcoholic extract } \\ \mathrm{BHA} & =\text { Butylated hydroxyl anisole }\end{array}$

MNU

$=\mathrm{N}$-nitroso $-\mathrm{N}$-methylurea

FRS

$=$ Free Radical Scavenging

\section{REFERENCES}

[1] Obolskiy D, Pischel I, Siriwatanametanon N, Heimrich M. Garcinia mangostana L.: Phytochemical and Pharmacological Review. Phytother Res 2009; 23: 1047-65. http://dx.doi:10.1002/ptr.2730

[2] Ramage CM, Sando L, Peace CP, Carroll BJ, Drew RA. Genetic diversity revealed in the apomictic fruit species Garcinia Mangostana L. Euphytica 2004; 136: 1-10. http://dx.doi.org/10.1023/B:EUPH.0000019456.06040.eb

[3] Rajarathnam S. Scope for Science and Technology of Fruits and Vegetables. In: Rajarathnam S, Ramteke RS, Eds. Advances in Preservation and Processing Technologies of Fruits and Vegetables, New India Publishing Agency, Pitam Pura, New Delhi 2011a; pp. 701- 741.

[4] Corner EJH. Mangosteen family. In Wayside Trees of Malaya. Malayan Nature Society: Kuala Lumpur 1988.

[5] Farnsworth RN, Bunyapraphatsara N. Garcinia mangostana Linn. In Thai Medicinal Plants. Prachachon Co., Ltd.: Bangkok 1992; 160-162.

[6] Yu L, Zhao M, Yang B, Zhao Q, Jiang Y. Phenolics from hull of Garcinia mangostana fruit and their anti-oxidant activities. Food Chem 2007; 104: 176-81.

http://dx.doi:10.1016/j.foodchem.2006.11.018

[7] Peres V, Nagem TJ. Trioxgenated naturally occurring xanthones. Phytochem 1997; 44: 191-214.

http://dx.doi:10.1016/S0031-9422(96)00421-9

[8] Fu C, Loo EK, Chia FP, Huang D. Oligomeric proanthocyanidins from mangosteen pericarps. J Agric Food Chem 2007; 55: 7689-94. http://dx.doi:10.1021/jf071166n

[9] Thompson LU. Potential health benefits and problems associated with anti-nutrients in foods. Food Res Internat 1993; 26: 131-49. http://dx.doi:10.1016/0963-9969(93)90069-U

[10] Du CT, Francis FJ. Anthocyanins of mangosteen Garcinia mangostana. J Food Sci 1997; 42: 1667-8. http://dx.doi:10.1111/j.1365-2621.1977.tb08452.x

[11] Rajarathnam $S$, Further Considerations in Fruit and Vegetable Technologies. In: Rajarathnam S, Ramtake RS, Eds. Advances in Preservation and Processing Technologies of Fruits and vegetables. New India Publishing Agency, Pitam Pura, New Delhi 2011b; pp. 1-37.

[12] Soong YY, Barlow PJ. Antioxidant activity and phenolic content of selected fruit seeds. Food Chem 2004; 88: 411-7. http://dx.doi:10.1016/j.foodchem.2004.02.003

[13] Jayaprakash GK, Singh RP, Sakariah, KK. Antioxidant activity of grape seed (Vitis vinifera) extracts on peroxidation models in vitro. Food Chem 2001; 73: 285-90. http://dx.doi:10.1016/S0308-8146(00)00298-3

[14] Li YF, Guo CJ. Yang J, Wei J, Xu J, et al. Evaluation of antioxidant properties of pomegranate peel extract in comparison with pomegranate pulp extract. Food Chem 2006; 96: 254-60. http://dx.doi:10.1016/j.foodchem.2005.02.033

[15] Ma F, Cheng L, The sun-exposed peel of apple fruit has higher xanthophylls cycle-dependent thermal dissipation and antioxidants of ascorbate-glutathrone pathway than the shaded peel. Plant Sci 2003; 165: 819-27. http://dx.doi:10.1016/S0168-9452(03)00277-2

[16] Guo C, Yang J, Wei J, Li Y, Xu J, et al. Antioxidant activities of peel, pulp and seed fractions of common fruits as determined by FRAP assay. Nutri Res 2003; 23:1719-26. http://dx.doi:10.1016/j.nutres.2003.08.005 
[17] Garrity AR, Morton GA, Morton JC, Nutraceutical mangosteen compositon. US patent 6730333 B1 20040504 2004.

[18] Nutritional Business Journal. NBJ's Supplement Business Report: an analysis of markets, trends, competition and strategy in the U.S. dietary supplement industry. Penton Media Inc: San Diego 2006; 186-200.

[19] Sen AK, Sarkar KK, Mazumder PC, Banerji N, Uusvuori R, et al. The structure of garcinonis $\mathrm{A}, \mathrm{B}$ and $\mathrm{C}$ : three new xanthones from Garcinia mangostana. Phytochem 1982; 21 : 1747-50.

[20] Mahabusarakam W, Kuaha K, Wilairat P, Taylor WC. Prenylated xanthones as potential antiplasmodial substances. Plant Medi 2006; 72: 912-6. http://dx.doi:10.1055/s-2006-947190

[21] Ji X, Avula B, Khan IA. Quantitative and qualitative determination of six xanthones in Garcinia mangostana L. by LC-PDA and LC-ESI-MS. J Pharmaco and Biomed Analy 2007; 43: 1270-6.

http://dx.doi:10.1016/j.jpba.2006.10.018

[22] Suksamarn S, Suwannapoch N, Phakodee W, Thanuhiranlert $\mathrm{J}$, Ratanaukul $\mathrm{P}$, et al. Antimycobacterial activity of prenylated xanthones from the fruits of Garcenia mangostana. Chemic and Pharmacolog Bulletin 2003; 51: 857-9.

http://dx.doi:org/10.1248/cpb.51.867

[23] Sakagami $Y$, linuma M, Piyasena KG and Dharmaratne HR. Antibacterial activity of $\alpha$-mangostin against vancomycin resistant Enterococci (VRE) and synergism with antibiotics. Phytomedicine 2005; 12: 203-8. http://dx.doi:10.1016/.j.phymed.2003.09.012

[24] Gopalakrishnan G, Banumathi B, Suresh G. Evaluation of the antifungal activity of natural xanthones from Garcinia mangostana and their synthetic derivatives. J Nat Prod 1997; 60: 519-24.

http://dx.doi:10.1021/np970165u

[25] Nakatani K, Yamakuchi T, Kondo N, Arakawa T, Oosawa K, et al. Gamma-Mangostin inhibits inhibitor - $\alpha \mathrm{B}$ kinase activity and decreases lipopolysaccharide induced cyclooxygenase-2 gene expression in C6 rat gliomo cells. Mol Pharmacol 2004; 66: $667-74$

http://dx.doi:10.1124/mol.104.002626

[26] Jung HA, Su BN, Keller WJ and Kinghorn AD. Antioxidant xanthones from pericarp of Garcinia mangostana (mangosteen). J Agric Food Chem 2006; 54: 2077-82. http://dx.doi:10.1021/jf052649z

[27] Matsumoto K, Akao Y, Ohguchi K, Ito T, Tanaka T, Linuma $\mathrm{M}$, et al. Xanthones induce cell-cycle arrest and apoptosis in human colon cancer DLD-I cells. Bioorganic Medicinal Chemistry 2005; 13: 6064-9.

http://dx.doi:10.1016/j.bmc.2005.06.065

[28] Suksamrarn S, Komutib O, Ratananukul P, Chimnol N, Lartporn-matulee $\mathrm{N}$, et al. Cytotoxic Prenylated xanthones from the young fruit of Garcinia mangostana, Chem Pharmacolog Bulletin 2006; 54: 301-5. http://dx.doi:org/10.1248/cpb.54.301

[29] Nabandith V, Suzui M, Morioka T, Kaneshiro T. Kinjo T, Matsumoto $\mathrm{K}$, et al. Inhibitory effects of crude $\alpha$-mangostin. A xanthone derivatrive, on two different categories of colon preneoplastic lesions induced by 1,2-dimethylhydrazine in the rat. Asian Pac J Cancer Preven 2004; 5: 433-8.

[30] Shashirekha MN, Dharmesh SM, Rajarathnam S. A process for preparation of beverage and jelly from mangosteen fruit rind. 2934 /DEL/11 dt. 12-10-2011.

[31] Lo KM, Cheung PCK. Antioxidant activity of extracts from the fruiting bodies of Agrocybe aegerita var. Alba. Food Chem 2005; 89: 533-9.

http://dx.doi:10.1016/j.foodchem.2004.03.006

[32] Nethravathi GP, Sathisha UV, Shylaja M Dharmesh, Shashirekha MN. Rajarathnam S. Anti-oxidant Activity of Indigenous Edible Mushrooms. J Agric Food Chem 2006; 54 9764-72. http://dx.doi:10.1021/jf0615707

[33] Siddaraju MN, Dharmesh SM. Inhibition of gastric $\mathrm{H}_{+-} \mathrm{K}_{+}-$ ATPase and $H$. Pylori growth by phenolic antioxidants of Zingiber officinale. Molecular Nutri Food Res 2007; 51: 32432. http://dx.doi:10.1002/mnfr.200600202

[34] Harish Nayaka MA, Sathisha UV, Manohara MP Chandrashekara KB, Dharmesh SM. Cytoprotective and antioxidant activity studies of jaggery sugar. Food Chem 2009; 115: 113-8.

http://dx.doi:10.1016/j.foodchem.2008.11.067

[35] Sathisha UV, Smitha L, Dharmesh SM. Antiproliferative, antioxidant and cyto/DNA protective properties in Andrographis serpyllifolia: Role of Andrographolide and phenolic acids. J Comp Integr Med 2009; 6: 1553-3840. http://dx.doi:10.2202/1553-3840.1252

[36] Wulf L, Nagel CW. Analysis of phenolic acids and flavonoids by HPLC. J Chromatography 1976; 116: 271-9. http://dx.doi:10.1016/S0021-9673(00)89898-2

[37] Walker EB. HPLC analysis of selected xanthones in mangosteen fruit. J Separation Sci 2007; 30: 1229-34. http://dx.doi:10.1002/jssc.200700024

[38] Stone H, Sidle J, Oliver S, Woolsey A, Singleton RC. Sensory evaluation by quantitative descriptive analysis. Food Technol 1974; 28: 24-34.

[39] APHA American Public Health Association. Compendium of methods for the microbiological examination of foods. In Downes FP, Ito K (eds), $4^{\text {th }}$ edn. Washington DC. 2001.

[40] Pedraza CJ, Cárdenas RN, Rozco IM, Pérez JM. Medicinal properties of mangosteen (Garcinia mangostana). Food Chem Toxicol 2008; 46: 3227-39. http://dx.doi:10.1016/j.fct.2008.07.024

[41] Nakatani K, Atsumi M, Arakawa T, Oosawa K, Shumura S, et al. Inhibitions of histamine release and prostaglandin E2 synthesis mangosteen, a Thai medicinal plant. Biol Pharm Bull 2002; 25: 1137-41. http://dx.doi:10.1248/bpb.25.1137

[42] Nakatani K, Nakahata N, Arakawa T, Yasuda H, Ohizumi Y Inhibition of cyclooxygenase and prostaglandin $\mathrm{E}_{2}$ synthesis by gamma-mangostin, a xanthone derivative in mangosteen, in C6 rat glioma cells. Biochem Pharmacol 2002; 63: 73-9. http://dx.doi:10.1016/S0006-2952(01)00810-3

[43] Matsumoto K, Akao Y, Kobayashi E, Ohguchi K, Ito T, et al. 2003. Induction of apoptosis by xanthones from mangosteen in human leukemia cell lines. J Nat Prod 2003; 66: 1124-7. http://dx.do:10.1021/np020546u

\section{DOI: http://dx.doi.org/10.6000/1927-3037.2014.03.04.1}

(c) 2014 Nanjarajurs et al.; Licensee Lifescience Global.

This is an open access article licensed under the terms of the Creative Commons Attribution Non-Commercial License (http://creativecommons.org/licenses/by-nc/3.0/) which permits unrestricted, non-commercial use, distribution and reproduction in any medium, provided the work is properly cited. 